\title{
Purification and Characterization of a 2-Oxoglutarate-linked ATP-independent Deacetoxycephalosporin C Synthase of Streptomyces lactamdurans
}

\author{
By JESÚS CORTÉS, JUAN F. MARTÍN,* JOSÉ M. CASTRO, \\ LEONILA LÁIZ AND PALOMA LIRAS \\ Departamento de Microbiologia, Facultad de Biologia, Universidad de León, León, Spain
}

(Received 9 March 1987; revised 8 June 1987)

\begin{abstract}
The deacetoxycephalosporin C (DAOC) synthase (expandase) of Streptomyces lactamdurans was highly purified, as shown by SDS-PAGE and isoelectric focusing. The enzyme catalysed the oxidative ring expansion that converts penicillin $\mathrm{N}$ into DAOC. The enzyme was very unstable but could be partially stabilized in $25 \mathrm{~mm}$-Tris/ $\mathrm{HCl}, \mathrm{pH} 9 \cdot 0$, in the presence of DTT $(0 \cdot 1 \mathrm{mM})$. The enzyme required 2-oxoglutarate, oxygen and $\mathrm{Fe}^{2+}$, but did not need ATP, ascorbic acid, $\mathrm{Mg}^{2+}$ or $\mathrm{K}^{+}$. The optimum temperature was between 25 and $30^{\circ} \mathrm{C}$. The DAOC synthase showed a high specificity for the penicillin substrate. Only penicillin $\mathrm{N}$ but not isopenicillin $\mathrm{N}$, penicillin $\mathrm{G}$ or 6-aminopenicillanic acid served as substrates. 2-Oxoglutarate analogues were not used as substrates although 2-oxobutyrate and 3-oxoadipate inhibited the enzyme by $100 \%$ and $56 \%$ respectively. The enzyme was strongly inhibited by $\mathrm{Cu}^{2+}, \mathrm{Co}^{2+}$ and $\mathrm{Zn}^{2+}$. The apparent $K_{\mathrm{m}}$ values for penicillin $\mathrm{N}$, 2-oxoglutarate and $\mathrm{Fe}^{2+}$ were $52 \mu \mathrm{M}, 3 \mu \mathrm{M}$ and $71 \mu \mathrm{M}$ respectively. The enzyme was a monomer with a molecular mass of $27000 \mathrm{Da} \pm 1000$.
\end{abstract}

\section{INTRODUCTION}

The biosynthesis of cephalosporin C in Acremonium chrysogenum (syn. Cephalosporium acremonium) and cephamycin C in Streptomyces clavuligerus proceeds through a biosynthetic pathway that includes the oxidative conversion of the five-membered intermediate penicillin $\mathrm{N}$ into the six-membered deacetoxycephalosporin C (ring expansion) (Fig. 1) (Kohsaka \& Demain, 1976; Yoshida et al., 1978; Baldwin et al., 1981; Jensen et al., 1982). The conversion of penicillin $\mathrm{N}$ into deacetoxycephalosporin $\mathrm{C}$ (DAOC) in these micro-organisms is catalysed by the DAOC synthase (the ring expanding enzyme or expandase), a dioxygenase requiring oxygen, 2-oxoglutarate, $\mathrm{Fe}^{2+}$, ascorbic acid and ATP in A. chrysogenum (Hook et al., 1979; Kupka et al., $1983 \mathrm{~b}$ ). The DAOC synthase of $S$. clavuligerus does not seem to require ATP (or only to a very small extent) or ascorbic acid (Jensen et al., 1982). However, the instability of these enzymes has hampered the purification studies and therefore some degree of ambiguity in the cofactor requirements still persists. In A. chrysogenum the DAOC synthase and the DAOC hydroxylase appear to be located in the same protein (Scheidegger et al., 1984) whereas in $S$. clavuligerus they appear to be separate enzymes (Jensen et al., 1985).

The ability to synthesize cephamycins is widely distributed among actinomycetes. More than 25 different species of Streptomyces are known to produce cephamycins (Martin, 1981). However, the enzymes involved in the biosynthesis of cephamycins in those species have not been characterized with the exception of some of the enzymes in $S$. clavuligerus. It has been assumed, but is not yet proven, that cephamycins arise in all Streptomyces from a pathway which involves the same type of ring expansion enzyme as found in A. chrysogenum.

Abbreviation: DAOC, deacetoxycephalosporin C. 
<smiles>CC1(C)SC2C(NC(=O)CCC(N)C(=O)O)C(=O)N2C1C(=O)O</smiles><smiles>CC1=C(C(=O)O)N2C(=O)C(NC(=O)CC(N)C(=O)O)C2SC1</smiles>

Fig. 1. Ring-expanding reaction catalysed by DAOC synthase that converts penicillin $\mathrm{N}$ into DAOC. Note the conversion of the five-membered thiazolidine ring of penicillin into the six-membered dihydrothiazine ring of the cephalosporins.

S. lactamdurans (syn. Nocardia lactamdurans) is a cephamycin-producing organism (Stapley et al., 1972). Biosynthesis of cephamycin $C$ in this strain and its regulation by carbon and nitrogen catabolism have been studied: synthesis of the DAOC synthase is repressed by carbon catabolism (Cortés et al., 1986) and nitrogen source regulation (Castro et al., 1985).

In order to get a better understanding of the regulatory mechanisms that control the synthesis and activity of this enzyme, it is necessary to clone the corresponding gene. As a first step, we have established a procedure to purify the DAOC synthase of S. lactamdurans.

\section{METHODS}

Micro-organisms and growth conditions. Streptomyces lactamdurans JC 1843, a stable variant that produces higher levels of cephamycin, was grown at $28^{\circ} \mathrm{C}$ in NYG medium in an orbital incubator ( 250 r.p.m.) as described by Castro et al. (1985).

Cell-free extracts. Cells ( $23 \mathrm{~g}$ wet $\mathrm{wt})$ were collected at $72 \mathrm{~h}$ when they contained maximum expandase activity and suspended in $60 \mathrm{ml}$ TPD buffer [25 mM-Tris/ $\mathrm{HCl}, \mathrm{pH} 7 \cdot 0,0 \cdot 1 \mathrm{~mm}$-dithiothreitol (DTT), $1 \mathrm{~mm}$ phenylmethylsulphonyl fluoride]. Cell-free extracts were obtained by sonication of the cells in a Branson Sonifier B-12 in an ice-bath for $15 \mathrm{~s}$ periods with $30 \mathrm{~s}$ intervals for a total time of $3 \mathrm{~min}$. The extracts were centrifuged at $15000 \mathrm{~g}$ for $15 \mathrm{~min}$ in a refrigerated $\left(4^{\circ} \mathrm{C}\right)$ centrifuge and then at $100000 \mathrm{~g}$, for $120 \mathrm{~min}$ in an ultracentrifuge (Beckman L8-70). The supernate ( $\mathrm{S} 100)$ was used as crude extract (Castro et al., 1985).

DAOC synthase assay. This was done by measuring the formation of DAOC from penicillin $\mathrm{N}$ at $25^{\circ} \mathrm{C}$. The reaction mixture contained in a final volume of $200 \mu \mathrm{l}: 0.2 \mathrm{~mm}$-penicillin $\mathrm{N}, 0.1 \mathrm{~mm}$-2-oxoglutarate, $0.25 \mathrm{~mm}$ $\mathrm{FeSO}_{4}, 50 \mathrm{~mm}-\mathrm{Tris} / \mathrm{HCl}, \mathrm{pH} 7 \cdot 0$, and enzyme $\left(150 \mu \mathrm{l}\right.$ of a preparation containing 5-10 mg protein $\left.\mathrm{ml}^{-1}\right)$. The DAOC produced was determined by a microbiological assay using $E$. coli Ess 22-31 as a test strain (Cortés et al., 1986). The residual substrate was removed by doing the bioassay in the presence of penicillinase (Bacillus cereus UL-1) lacking cephalosporinase activity. Penicillinase was mixed with TSB (Difco) ( $1 \%$ agar) at a final concentration of $50 \mu \mathrm{l}(\mathrm{ml} \text { medium })^{-1}$. Under these experimental conditions, the penicillin $\mathrm{N}$ present in the assay does not form inhibition zones (Cortés et al., 1984). The same reaction mixture was used to determine DAOC hydroxylase except that the deacetylcephalosporin $\mathrm{C}$ produced was determined by HPLC. Specific activities are given as pkat (pmol product formed $\left.\mathrm{s}^{-1}\right)(\mathrm{g} \text { protein })^{-1}$.

Separation and quantification of deacetoxycephalosporin $C$ and deacetylcephalosporin $C$. The antibiotic products which originated from the reactions were analysed by HPLC through a $\mu$ Bondapack $C 18$ (Waters) column $(30 \times$ $4 \mathrm{~mm}$ ) equilibrated with $10 \mathrm{~mm}$-acetate buffer $\mathrm{pH} \mathrm{4.7-acetonitrile}(99: 1, \mathrm{v} / \mathrm{v})$. The products were eluted by increasing linearly the flow, from $0.4 \mathrm{ml} \mathrm{min}^{-1}$ (time zero) to $2 \mathrm{ml} \mathrm{min}^{-1}$ at $3.5 \mathrm{~min}$ and to $3 \mathrm{ml} \mathrm{min}^{-1}$ at $5.5 \mathrm{~min}$. Under these conditions pure deacetoxycephalosporin $C$ showed a retention time of $5 \cdot 1 \mathrm{~min}$ and pure deacetylcephalosporin $\mathrm{C}$ eluted at $3.3 \mathrm{~min}$. 
Purification of DAOC synthase. The nucleic acids and nucleoproteins in the crude extract were precipitated by slowly adding a $1 \%(\mathrm{w} / \mathrm{v})$ solution of protamine sulphate in TPD buffer to the S100 extract $(1482 \mathrm{mg})$ at $4{ }^{\circ} \mathrm{C}$, to a final concentration of $0.1 \%$. The suspension was kept at $4{ }^{\circ} \mathrm{C}$ for $15 \mathrm{~min}$ and then centrifuged at $20000 \mathrm{~g}$ for $15 \mathrm{~min}$. The supernate was mixed slowly with solid ammonium sulphate (enzyme grade) by stirring. All DAOC synthase activity precipitated in the $50-70 \%$ saturation ammonium sulphate fraction. This precipitate was dissolved in $120 \mathrm{ml}$ TPD buffer and applied to a DEAE Sephacel column $(30 \times 1.5 \mathrm{~cm})$ equilibrated with $300 \mathrm{mM}-$ Tris/ $\mathbf{H C l}, \mathrm{pH} 9 \cdot 5$. The DAOC synthase activity was eluted with $300 \mathrm{mM}$ - Tris/ $\mathrm{HCl}$ in a linear $\mathrm{pH}$ gradient $(9 \cdot 5-$ 6.5). The active fractions were pooled and concentrated 4-fold in an Amicon ultrafiltration cell with a PM-10 membrane. The concentrated preparation $(11.2 \mathrm{mg}$ in $5 \mathrm{ml})$ was applied to a Sephadex $\mathrm{G}-75$ column $(70 \times 2.6 \mathrm{~cm}$, Pharmacia) equilibrated with TPD buffer and the enzyme eluted with a constant flow of $8 \mathrm{ml} \mathrm{h}^{-1}$. The whole purification procedure was done at $4{ }^{\circ} \mathrm{C}$. Protein was detected with an UV detector (Pharmacia) set at $0 \cdot 2$ and a REC-1 recorder (Pharmacia). The molecular mass of the purified enzyme was determined by gel filtration through Sephadex G-75 column $(70 \times 2.6 \mathrm{~cm})$ previously calibrated with the following standard proteins: cytochrome $c$ $(12.4 \mathrm{kDa})$, carbonic anhydrase $(29 \mathrm{kDa})$, ovalbumin $(45 \mathrm{kDa})$ and bovine serum albumin $(66 \mathrm{kDa})$.

$S D S-P A G E$. This was done as described by Laemmli (1970) in a BioRad Protean $16 \mathrm{~cm}$ vertical slab cell with circulating water at $4{ }^{\circ} \mathrm{C}$ for refrigeration, using $10 \%(\mathrm{w} / \mathrm{v})$ polyacrylamide. Each track was loaded with $15-50 \mu \mathrm{g}$ protein. The gels were stained with Coomassie Brilliant Blue R-250 or with silver nitrate. A set of molecular mass standards was used as controls.

Substrates and materials. DEAE Sephacel, Sephadex G-75 and G-100 (fine) were from Pharmacia. Penicillin N (95\% purity) was kindly donated by H. H. Peter (Ciba Geigy, Basel, Switzerland). Deacetoxycephalosporin C and deacetylcephalosporin $\mathrm{C}$ were a gift of F. Salto (Antibióticos, León, Spain). Isopenicillin N (62\% purity) was provided by P. van Dijck (Gist-Brocades, Delft, The Netherlands). The oxoacids and 2-oxoglutarate analogues tested were obtained from Sigma. All other chemicals were of reagent quality.

\section{RESULTS}

Cofactor requirements for optimum enzyme activity. The requirements of the DAOC synthase of $S$. lactamdurans were initially studied using a partially purified enzyme [160 pkat ( $\mathrm{g}$ protein $\left.)^{-1}\right]$ in comparison with the cofactors already described for the analogous enzymes of $S$. clavuligerus (Jensen et al., 1982) and A. chrysogenum (Hook et al., 1979). When different cofactors or substrates were omitted from the reaction mixture (Table 1) the results indicated that only penicillin $\mathrm{N}, 2$-oxoglutarate and $\mathrm{Fe}^{2+}$ ions were required for activity. Assays done under an atmosphere of nitrogen indicated that oxygen was also required., Ascorbate (a 2-electron donor), $\mathrm{KCl}, \mathrm{MgSO}_{4}$ and ATP were not necessary for activity, contrasting with the requirements of the expandase of $A$. chrysogenum. No variation in enzyme activity was found when the order of addition of the cofactors was altered. The reaction rate was linear for at least $3 \mathrm{~h}$.

Optimum temperature and protein concentration. The DAOC synthase activity increased linearly with protein concentration in the range $0-0.75 \mathrm{mg}$ protein $(\mathrm{ml} \text { assay mixture })^{-1}$. The optimum temperature for DAOC synthase activity was $25-30{ }^{\circ} \mathrm{C}$; about $90 \%$ of the activity remained at 20 or $35^{\circ} \mathrm{C}$, but the activity decresed rapidly at temperatures above $35^{\circ} \mathrm{C}$ or below $20{ }^{\circ} \mathrm{C} ; 15 \%$ of the activity remained at either 5 or $40{ }^{\circ} \mathrm{C}$. The stability of the enzyme at increasing temperature was measured by preincubating the enzyme for $60 \mathrm{~min}$ at different temperatures and then assaying the activity at $25^{\circ} \mathrm{C}$. The enzyme was stable up to $20-25^{\circ} \mathrm{C}$ but increasing the temperature to $30^{\circ} \mathrm{C}$ led to a $25 \%$ decrease in activity. The stability decreased linearly when the preincubation temperature was increased from 30 to $60{ }^{\circ} \mathrm{C}$ and no activity was observed after preincubation at $65^{\circ} \mathrm{C}$.

Optimum $\mathrm{pH}$ and $\mathrm{pH}$ stability. The DAOC synthase had a very broad $\mathrm{pH}$ optimum. Essentially the same activity was found when the buffers (50 mM-MOPS/ $\mathrm{NaOH}$ in the $\mathrm{pH}$ range $5 \cdot 0-7 \cdot 0$ and $50 \mathrm{~mm}$-Tris/ $\mathrm{HCl}$ in the $\mathrm{pH}$ range $7 \cdot 0-11 \cdot 0$ ) were adjusted from $\mathrm{pH} 5 \cdot 0$ to $\mathrm{pH} 11 \cdot 0$. However, the stability of the enzyme in $50 \mathrm{~mm}$-Tris/ $\mathrm{HCl}$ changed at the different $\mathrm{pH}$ values tested. Maximum

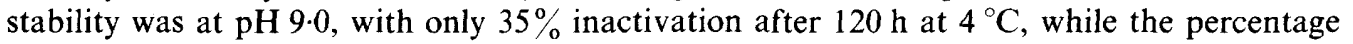
inactivation at $\mathrm{pH} 8.0$ and $7 \cdot 0$ was 70 and $80 \%$ respectively. The highest stability was observed when the enzyme was kept in $25 \mathrm{~mm}-\mathrm{Tris} / \mathrm{HCl}, \mathrm{pH} 9 \cdot 0$. When $25 \mathrm{~mm}-\mathrm{MOPS} / \mathrm{NaOH}$ or HEPES/KOH buffer at the same $\mathrm{pH}(9 \cdot 0)$ were used, activity was completely lost after only $72 \mathrm{~h}$. Phosphate buffers were not used since the enzyme activity is inhibited by phosphate (Cortés et al., 1986). Increasing the ionic strength of the Tris/ $\mathrm{HCl}$ buffer to $100 \mathrm{~mm}$ decreased the stability of the enzyme, reducing activity by $50 \%$ in $48 \mathrm{~h}$. 
Table 1. Substrate and cofactor requirements for DOAC synthase activity of $S$. lactamdurans

The assay mixture contained, in a final volume of $0.4 \mathrm{ml}$ : ascorbate $(2.8 \mathrm{~mm}) ; \mathrm{FeSO}_{4}(0.045 \mathrm{mM}) ; 2-$ oxoglutarate (1 mM); ATP $(0.5 \mathrm{mM}) ; \mathrm{KCl}(7.5 \mathrm{mM}) ; \mathrm{MgSO}_{4}(7.5 \mathrm{mM})$; penicillin $\mathrm{N}(0.2 \mathrm{mM})$; enzyme extract $(0.4 \mathrm{mg}$ protein in $0.3 \mathrm{ml})$; and $\mathrm{Tris} / \mathrm{HCl}$ buffer $(50 \mathrm{mM}, \mathrm{pH} 7.0)$.

\begin{tabular}{lr}
\multicolumn{1}{c}{$\begin{array}{c}\text { Substrate } \\
\text { omitted }\end{array}$} & $\begin{array}{r}\text { Specific activit } \\
\text { [pkat (g protein) }\end{array}$ \\
None & 160 \\
Ascorbic acid & 160 \\
FeSO $_{4}$ & 0 \\
2-Oxoglutarate & 0 \\
$\mathrm{ATP}$ & 160 \\
$\mathrm{KCl}$ & 160 \\
$\mathrm{MgSO}_{4}$ & 160 \\
Penicillin N & 0
\end{tabular}

Identification of the reaction product. The product of the reaction was active against $E$. coli but not against Micrococcus luteus and was insensitive to penicillin-specific $\beta$-lactamases, i.e. it showed the characteristics of a cephalosporin. When the product of the reaction (using a partially purified enzyme preparation obtained after Sephadex G-75 filtration) was analysed by reverse phase HPLC a new peak was found which was not present at the beginning of the reaction. This peak eluted with a retention time of $5.1 \mathrm{~min}$, and co-chromatographed with pure deacetoxycephalosporin C (Fig. 2). No peak corresponding to deacetylcephalosporin C (retention time $3.3 \mathrm{~min}$ ) was found even after $120 \mathrm{~min}$ incubation, suggesting that the DAOC synthase activity was free of DAOC hydroxylase activity.

Purification of DAOC synthase. The steps followed in the purification of the enzyme are summarized in Table 2 . All the DAOC synthase activity was recovered after treatment with protamine sulphate $(0.1 \%)$, with only a slight increase in purity. Fractionation with ammonium sulphate $(50-70 \%$ saturation) of the protamine sulphate supernate increased the enzyme purity 2 -fold, with a recovery of $72 \%$.

After this step several other purification procedures including dialysis, Sephadex G-25 gel filtration or ion exchange chromatography through DEAE Sephacel followed by elution with a concentration gradient of Tris/ $\mathrm{HCl}, \mathrm{pH} 7 \cdot 0(25-300 \mathrm{mM})$ were all unsuccessful leading to total loss of activity. Ion exchange chromatography in DEAE-HPLC also resulted in a considerable loss (about $95 \%$ ) of activity. These results probably reflect the enzyme instability discussed above.

Good purification was possible, however, by anion exchange chromatography in DEAESephacel followed by elution with a $\mathrm{pH}$ gradient of $300 \mathrm{~mm}-\mathrm{Tris} / \mathrm{HCl}$ in the $\mathrm{pH}$ range 6.5-9.5. Advantage was taken of the broad $\mathrm{pH}$ range of activity and stability of the enzyme at $\mathrm{pH} 9 \cdot 0$. As shown in Fig. 3, the enzyme eluted when the gradient reached a $\mathrm{pH}$ of 7.5 . Under these conditions a 20 -fold purification was obtained with a $15 \%$ recovery (Table 2 ). Although the recovery of activity was low, this step removed many of the contaminant proteins as judged by PAGE (see below). The Amicon-concentrated active samples $(11.2 \mathrm{mg}$ protein) were subsequently applied to a Sephadex G-75 column (Fig. 4), to give a final purification of 75.6fold, with a recovery of $19 \%$ of the activity (i.e. with slight increase in the recovery of activity over the previous step of purification). This increase in the recovery suggests that in the eluate of the anion exchange column by $\mathrm{pH}$ gradient, the enzyme is partially inhibited either by some inhibitor which is removed during gel filtration or by a $\mathrm{pH}$ effect. The active samples (Fig. 4) were pooled and kept frozen at $-70^{\circ} \mathrm{C}$. Attempts to further purify the enzyme by DEAEHPLC led to the loss of the enzyme activity.

Molecular mass. This was determined by gel filtration through a Sephadex G-75 column calibrated as described in Methods. The DAOC synthase eluted with a $K_{\mathrm{av}}$ of 0.484 , corresponding to a molecular mass of $27000 \mathrm{Da} \pm 1000$ (Fig. 4).

$S D S-P A G E$. The purity of enzyme samples after the purification steps was followed by SDSPAGE (Fig. 5). The main purification step was anion exchange chromatography followed by 

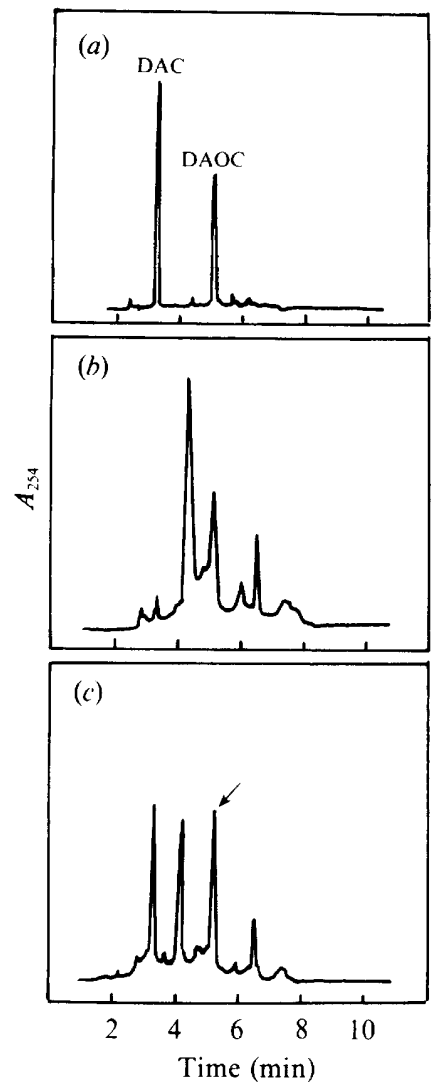

Fig. 2. HPLC analysis of the reaction product(s) of DAOC synthase. (a) Separation of a mixture of pure deacetylcephalosporin $\mathrm{C}$ (DAC) (retention time $3.3 \mathrm{~min}$ ) and deacetoxycephalosporin C (DAOC) (retention time $5.1 \mathrm{~min}$ ). (b) Reaction products. (c) A mixture of the reaction products with the pure antibiotics used in $(a)$. The peak of deacetoxycephalosporin $\mathrm{C}$ is indicated by an arrow.

Table 2. Partial purification of DAOC synthase of S. lactamdurans

\begin{tabular}{|c|c|c|c|c|c|}
\hline Purification step & $\begin{array}{c}\text { Activity } \\
\text { (pkat) }\end{array}$ & $\begin{array}{l}\text { Protein } \\
\text { (mg) }\end{array}$ & $\begin{array}{c}\text { Specific } \\
\text { activity } \\
\left.\text { [pkat }(\mathrm{g} \text { protein })^{-1}\right]\end{array}$ & $\begin{array}{c}\text { Recovery } \\
\text { of activity } \\
(\%)\end{array}$ & $\begin{array}{l}\text { Purification } \\
\quad(- \text { fold })\end{array}$ \\
\hline Crude extract & 119 & 1482 & $80 \cdot 2$ & 100 & $1 \cdot 0$ \\
\hline Protamine sulphate & 117 & 1364 & 85.7 & 98 & $1 \cdot 1$ \\
\hline $\begin{array}{l}\text { Ammonium sulphate }(50-70 \%) \\
\text { precipitate }\end{array}$ & 86 & 510 & $168 \cdot 0$ & 72 & $2 \cdot 0$ \\
\hline Anion exchange-pH gradient & 18 & $11 \cdot 2$ & $1607 \cdot 1$ & 15 & $20 \cdot 0$ \\
\hline Sephadex G-75 gel filtration & 23 & 3.8 & $6052 \cdot 6$ & 19 & $75 \cdot 6$ \\
\hline
\end{tabular}

elution with a pH gradient (Fig. 5, lane E). Several of the contaminant proteins were removed during the subsequent gel filtration through Sephadex G-75 (Fig. 5, lane F). The DAOC synthase appeared as an intense band with minor contaminant proteins after Sephadex G-75 filtration (Fig. 5, lane F). The molecular mass estimated by PAGE was $28000 \mathrm{Da}$ which agrees with the molecular mass established by gel filtration.

Kinetics of the DAOC synthase. The kinetics of DAOC synthase for the substrate and cofactors of the reaction were determined using enzyme of the highest purity $\left(1600 \mathrm{pkat}^{-1}\right)$. In one experiment the concentration of 2-oxoglutarate $(1-50 \mu \mathrm{M})$ was varied while the other two 


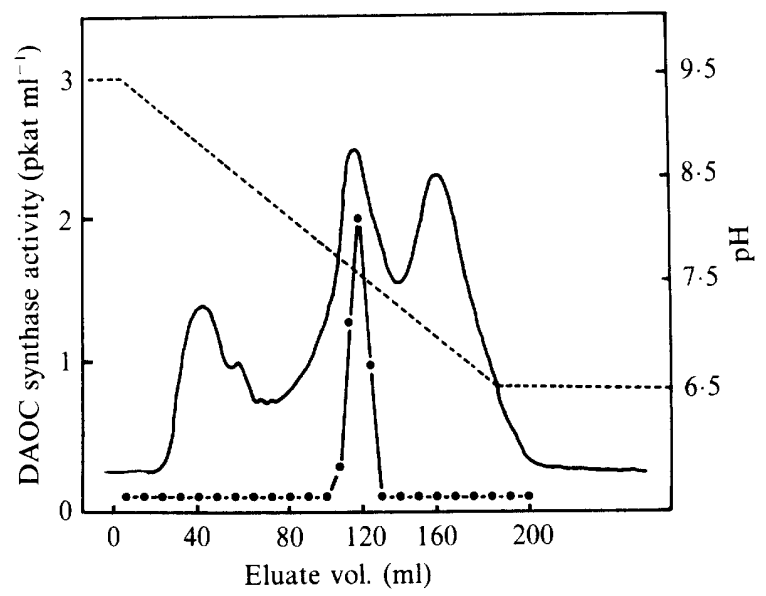

Fig. 3. Anion exchange chromatography of DAOC synthase in DEAE Sephacel. The enzyme was eluted using a pH gradient. - DAOC synthase activity;,$- A_{280}$ (protein); ---, $\mathrm{pH}$ gradient $(9 \cdot 5$ to 6.5) (300 mM-Tris/ $\mathrm{HCl}$ buffer $)$.
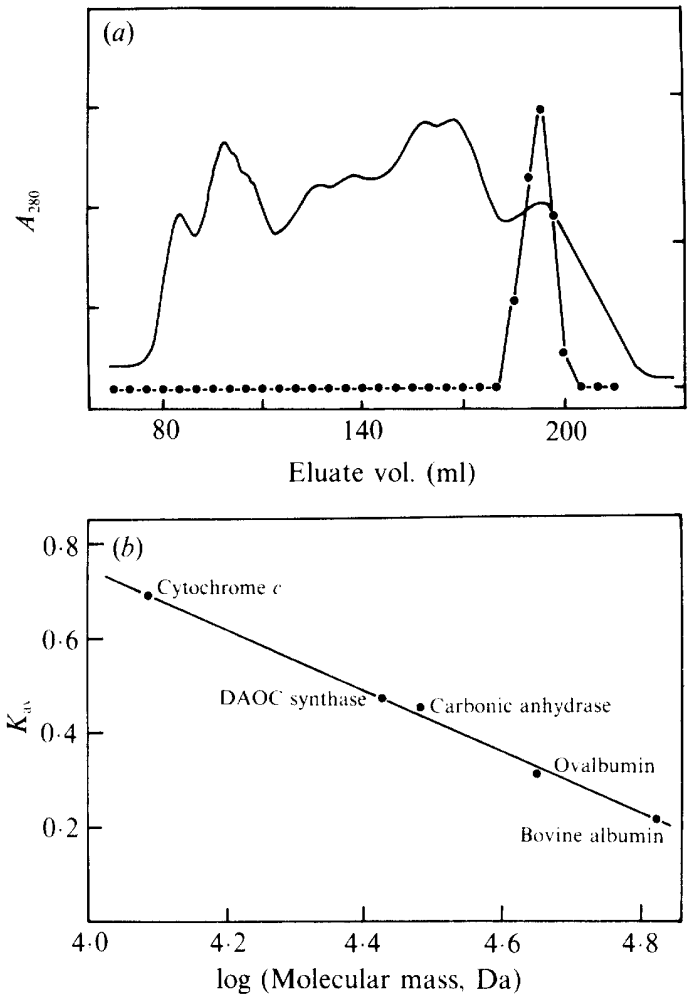

Fig. 4. Gel filtration of DAOC synthase through Sephadex G-75. (a) Purification of concentrated extract. - DAOC synthase activity; - - $A_{280}$ (protein). (b) Determination of molecular mass in comparison with protein standards. The DAOC synthase had a molecular mass of $27000 \mathrm{Da} \pm 1000$.

substrates were kept at the concentrations indicated in Methods. In another experiment, the concentration of penicillin $\mathrm{N}(0 \cdot 01-0 \cdot 15 \mathrm{mM})$ or $\mathrm{Fe}^{2+}(0 \cdot 045-1 \mathrm{~mm})$ were varied while the other parameters were kept constant. The $K_{\mathrm{m}}$ and $V_{\max }$ in every case were determined from Lineweaver-Burk double reciprocal plots. For penicillin $\mathrm{N}$, the apparent $K_{\mathrm{m}}$ was $52 \mu \mathrm{M}$ and the 


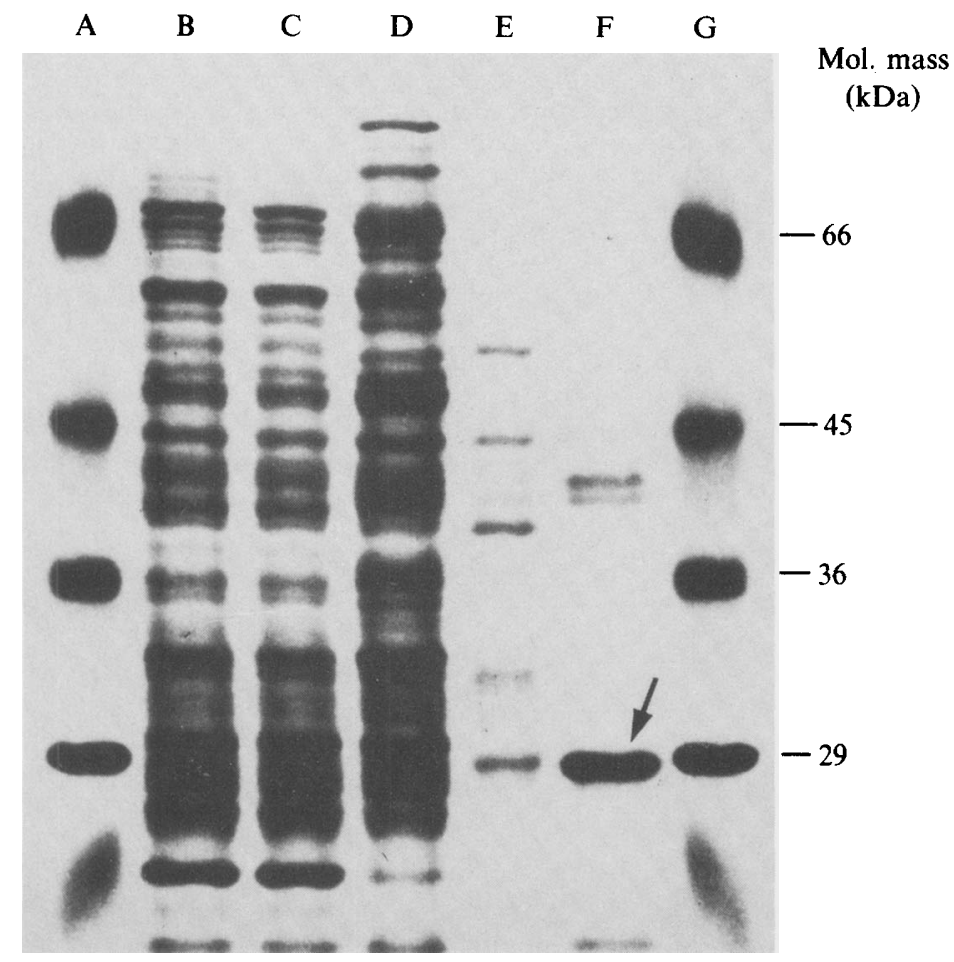

Fig. 5. Electrophoresis in SDS-PAGE of samples of DAOC synthase after different steps of purification. Lanes A and G, molecular mass markers. Lane B, S100 cell-free extracts; lane C, protamine sulphate supernate; lane $\mathrm{D}$, ammonium sulphate $(50-70 \%)$ precipitate; lane $\mathrm{E}$, active fractions eluted from DEAE Sephacel using a pH gradient; lane F, active fraction obtained after Sephadex G-75 gel filtration. The DAOC synthase band is indicated by an arrow. About $50 \mu \mathrm{g}$ protein were loaded in tracks $A$ to $C$; tracks $E$ and $F$ were loaded with $15 \mu \mathrm{g}$ protein.

$V_{\max }$ was $7.6 \mathrm{pmol}$ DAOC formed $(\mathrm{ml} \cdot \mathrm{s})^{-1}$. The apparent $K_{\mathrm{m}}$ for 2-oxoglutarate was $3 \mu \mathrm{M}$ with a $V_{\max }$ of $6.6 \mathrm{pmol}(\mathrm{ml} \cdot \mathrm{s})^{-1}$. Finally, for the cofactor $\mathrm{Fe}^{2+}$, the apparent $K_{\mathrm{m}}$ was $71 \mu \mathrm{M}$ with a $V_{\max }$ of $7 \cdot 1 \mathrm{pmol}(\mathrm{ml} \cdot \mathrm{s})^{-1}$.

Substrate specificity. Enzyme preparations from the last purification step (Sephadex G-75 filtration) were used to study the substrate and cofactor requirements of the DAOC synthase. Isopenicillin $\mathrm{N}$, penicillin $\mathrm{G}$ and 6-aminopenicillanic acid (all $1 \mathrm{~mm}$ ) were tested either as substrates of the expandase (instead of the natural substrate penicillin $\mathrm{N}$ ) or as competitive inhibitors of penicillin $\mathrm{N}$. None of these $\beta$-lactams were substrates of the DAOC synthase, indicating a high substrate specificity. Moreover, none of these compounds inhibited the formation of DAOC from penicillin $\mathrm{N}$.

Effect of 2-oxoglutarate analogues and of cations. Several amino acids and oxoacids were tested in order to see if they could either serve as cofactors or compete with 2-oxoglutarate. Neither glutamate, succinate, 2-oxoisovalerate, 2-oxocaproate nor oxalacetate had any effect on the reaction, but 2-oxobutyrate completely inhibited the formation of deacetoxycephalosporin $\mathrm{C}$ and 3-oxoadipate produced a $56 \%$ inhibition (Table 3). However, these two analogues could not be used as cofactor in the reaction since no DAOC was formed when 2-oxobutyrate or 3oxoadipate were used instead of 2-oxoglutarate.

$\mathrm{K}^{+}, \mathrm{Na}^{+}, \mathrm{Hg}^{2+}$ or $\mathrm{Fe}^{3+}$ (all $1 \mathrm{mM}$ ) did not affect enzyme activity but $\mathrm{Co}^{2+}, \mathrm{Zn}^{2+}$ and $\mathrm{Cu}^{2+}$ strongly inhibited the formation of DAOC (79, 84 and $100 \%$ respectively). $\mathrm{Fe}^{3+}$ did not inhibit enzyme activity and it could be used instead of $\mathrm{Fe}^{2+}$ under the reducing conditions existing in the reaction mixture. 
Table 3. Effect of cations and 2-oxoglutarate analogues on DAOC synthase activity

The assays were done using a purified DAOC synthase preparation obtained after Sephadex G-75 filtration. In this particular experiment, the control reaction mixture contained 2-oxoglutarate $(0.05 \mathrm{mM})$ and $\mathrm{Fe}^{2+}(225 \mu \mathrm{M})$. No activity was obtained when 2-oxoglutarate in the reaction mixture was replaced by any of the 2-oxoglutarate analogues or when $\mathrm{Fe}^{2+}$ was replaced by any of the other ions indicated in the table (except $\mathrm{Fe}^{3+}$ ).

\begin{tabular}{|c|c|c|}
\hline Addition & $\begin{array}{c}\text { Specific activity } \\
{\left[\text { pkat }(\mathrm{g} \text { protein })^{-1}\right]}\end{array}$ & $\begin{array}{l}\text { Inhibitior } \\
\qquad \%)\end{array}$ \\
\hline None (control) & 970 & 0 \\
\hline Glutamate $(0.1 \mathrm{~mm})$ & 970 & 0 \\
\hline Succinate $(0.1 \mathrm{~mm})$ & 970 & 0 \\
\hline 2-Oxoisovalerate $(0.1 \mathrm{~mm})$ & 970 & 0 \\
\hline 2-Oxocaproate $(0.1 \mathrm{~mm})$ & 970 & 0 \\
\hline 2-Oxobutyrate $(0.1 \mathrm{~mm})$ & 0 & 100 \\
\hline Oxalacetate $(0.1 \mathrm{~mm})$ & 970 & 0 \\
\hline 3-Oxoadipate $(0 \cdot 1 \mathrm{~mm})$ & 420 & 56 \\
\hline $\mathrm{Fe}^{3+}(1 \mathrm{mM})$ & 970 & 0 \\
\hline $\mathrm{Hg}^{2+}(1 \mathrm{mM})$ & 970 & 0 \\
\hline $\mathrm{Co}^{2+}(1 \mathrm{mM})$ & 210 & 79 \\
\hline $\mathrm{Cu}^{2+}(1 \mathrm{mM})$ & 0 & 100 \\
\hline $\mathrm{Zn}^{2+}(1 \mathrm{mM})$ & 140 & 84 \\
\hline $\mathrm{K}^{+}(1 \mathrm{mM})$ & 970 & 0 \\
\hline $\mathrm{Na}^{+}(1 \mathrm{mM})$ & 970 & 0 \\
\hline
\end{tabular}

\section{DISCUSSION}

$S$. lactamdurans and other micro-organisms that synthesize cephalosporins and cephamycins do so by oxidative ring expansion of penicillin $\mathbf{N}$ to deacetoxycephalosporin $\mathrm{C}$. Penicillin $\mathbf{N}$ itself is formed in this micro-organism by cyclization of the tripeptide $\delta$-(L- $\alpha$-aminoadipyl)-Lcysteinyl-D-valine (Castro et al., 1988) followed by an L to D epimerization of the $\alpha$-aminoadipyl moiety during the conversion of isopenicillin $\mathrm{N}$ to penicillin $\mathrm{N}$ (Castro et al., 1985).

Because of the instability of the DAOC synthases of $A$. chrysogenum (Yoshida et al.,1978) and S. clavuligerus (Jensen et al., 1982) and the inherent difficulty in purifying them (Kupka et al., $1983 a, b$; Jensen $e t a l ., 1985$ ) some uncertainty concerning the necessary cofactors has remained. The DAOC synthase of $S$. lactamdurans requires oxygen and 2-oxoglutarate and is an intermolecular dioxygenase functionally similar to the enzymes of $A$. chrysogenum and $S$. clavuligerus, which suggests a common evolutionary origin of these enzymes in the different producers of cephalosporin and cephamycin. However, there are some differences in the cofactor requirements and in the molecular mass. The DAOC synthase of $S$. lactamdurans requires oxygen, a thiol-containing reducing agent (DTT), $\mathrm{Fe}^{2+}$ and 2-oxoglutarate as cofactors but in contrast to the enzyme of $A$. chrysogenum (Hook et al., 1979; Kupka et al., 1983a, $b$; Felix et al., 1981) it does not require ATP, ascorbic acid, or $\mathrm{Mg}^{2+}$ or $\mathrm{K}^{+}$ions. Therefore, it should be named a synthase rather than synthetase. The DAOC synthase of $S$. lactamdurans shows more similarity to the enzyme of $S$. clavuligerus that also showed an absolute requirement for 2oxoglutarate but does not need ATP (Jensen et al., 1982).

The apparent $K_{\mathrm{m}}$ for 2-oxoglutarate of the DAOC synthase of $S$. lactamdurans was $3 \mu \mathrm{M}$ which is an order of magnitude less (i.e. the enzyme shows more affinity) than the $K_{\mathrm{m}}$ value of the enzyme of $A$. chrysogenum $(40 \mu \mathrm{M})$. The absolute requirement for 2-oxoglutarate of the DAOC synthase of $S$. lactamdurans, which has also been shown unequivocally in the fungal enzyme (Kupka et al., 1983a) in contrast to previous claims (Hook et al., 1979), indicates that the expandases characterized so far are intermolecular dioxygenases which use 2-oxoglutarate as substrate (Abbot \& Underfriend, 1974). The requirement for 2-oxoglutarate of the DAOC synthase of $S$. lactamdurans was rather specific since neither glutamate, succinate, oxalacetate, 2-oxobutyrate, 2-oxoisovalerate, 2-oxocaproate or 3-oxoadipate were used as cofactors. 2Oxobutyrate completely inhibited enzyme activity and 3-oxoadipate produced a $56 \%$ reduction, probably as a result of a competitive inhibition. For the fungal expandase, 2-oxoadipate was an 
alternative cofactor with about $30 \%$ of the activity of 2 -oxoglutarate. This would suggest that the fungal enzyme has a broader cofactor specificity. However, the authors pointed out that there was a possibility that contaminant transaminases provide 2-oxoglutarate (from glutamate) since the study was done with a partially purified enzyme (Kupka et al., 1983a).

Ascorbic acid stimulates the fungal DAOC synthase (Hook et al., 1979) and the same apparently occurs in $S$. clavuligerus (Jensen et al., 1982). The $S$. lactamdurans enzyme is different in that it lacks the requirement for ascorbic acid, a reducing cofactor of standard dioxygenases (Myllilla et al., 1978). However, it is important to keep in mind that the enzyme was always kept in DTT to preserve activity.

In $S$. lactamdurans the expandase reaction proceeds independently of the order in which the substrate and cofactors are added to the reaction mixture, in contrast to the behaviour described for the DAOC synthase of $A$. chrysogenum (Shen et al., 1984).

The DAOC synthase of $S$. lactamdurans showed a high specificity for the nature of the side chain in the penicillin substrate. Only penicillin $\mathrm{N}$, but not isopenicillin $\mathrm{N}$, penicillin $\mathrm{G}$ or 6aminopenicillanic acid served as substrates. The expandases of $A$. chrysogenum (Kupka et al., 1983 a) and $S$. clavuligerus (Jensen et al., 1982) showed the same specificity. However, unlike the fungal enzyme, the DAOC synthase of $S$. lactamdurans was not inhibited by penicillin G.

The ring expansion activity is released from the mycelium by sonication (i.e, is not associated with the membrane systems) as occurs also with the expandases of $A$. chrysogenum and $S$. clavuligerus (Kupka et al., $1983 a$; Jensen et al., 1982). The enzyme of $S$. lactamdurans has a molecular mass of $27 \mathrm{kDa}$ slightly lower than that of the enzyme of $A$. chrysogenum $(31 \mathrm{kDa})$ (Scheidegger et al., 1984) and $S$. clavuligerus $(29.5 \mathrm{kDa}$ ) (Jensen et al., 1985). It appears to be a monomer since the molecular mass of the natural (non-denatured) form, determined by gel filtration is identical to that of the SDS-denatured protein as estimated by SDS-PAGE.

Despite the instability characteristic of all expandases, the DAOC synthase of $S$. lactamdurans was purified to near homogeneity by a combination of chromatographic techniques, thanks to the development of an ion exchange procedure based on a $\mathrm{pH}$ gradient.

The purified enzyme showed no DAOC hydroxylase activity, which is, however, present in cephamycin-synthesizing cells, suggesting that the two activities are separated in the chromatographic procedures and therefore are probably two separate enzymes as in $S$. clavuligerus (Jensen et al., 1985), in contrast to A. chrysogenum, where they appear to be located in a single protein (Scheidegger et al., 1984). In summary, the expandase of $S$. lactamdurans is more closely related to the enzyme of $S$. clavuligerus than to the enzyme of $A$. chrysogenum, which suggests that even if they have a common evolutionary origin the fungal enzyme diverged differently from the bacterial (streptomycete) DAOC synthases.

This work was supported by grants of the CAICYT, Madrid and the Diputación Provincial de León, Spain. J. Cortés, J. M. Castro and L. Láiz were supported by fellowships of the Ministry of Foreign Affairs, Madrid, the PFPI-Ministry of Education and Science, and the Diputación de León respectively. We acknowledge M. P. Puertas, B. Martín and N. Calvo for their excellent technical assistance.

\section{REFERENCES}

Aвbot, M. T. \& UNDERfRiend, S. (1974). $\alpha$-Ketoglutarate-coupled dioxygenases. In Molecular Mechanisms of Oxygen Activation, pp. 167-214. Edited by O. Hayashi. London: Academic Press.

Baldwin, J. E., Keeping, J. W., Singh, P. D. \& Vallejo, C. A. (1981). Cell-free conversion of isopenicillin $\mathrm{N}$ into deacetoxycephalosporin $\mathrm{C}$ by Cephalosporium acremonium mutant M-0198. Biochemical Journal 194, 649-651.

Castro, J. M., Liras, P., Cortés, J. \& Martin, J. F. (1985). Regulation of $\alpha$-aminoadipyl-cysteinylvaline, isopenicillin $\mathrm{N}$ synthase, isopenicillin $\mathrm{N}$ epimerase and deacetoxycephalosporin $\mathrm{C}$ synthase by nitrogen sources in Streptomyces lactamdurans. Applied Microbiology and Biotechnology 22, 32-40.
Castro, J. M., Liras, P., Láiz, L., Cortés, J. \& Martín, J. F. (1988). Purification and characterization of the isopenicillin $\mathbf{N}$ synthase of Streptomyces lactamdurans. Journal of General Microbiology 134 (in the Press).

Cortés, J., Liras, P., Castro, J. M., Romero, J. \& MARTIN, J. F. (1984). Regulation of the biosynthesis of cephamycin C by Streptomyces lactamdurans. Biochemical Society Transactions 12, 863-864.

Cortés, J., Liras, P., Castro, J. M. \& Martin, J. F. (1986). Glucose regulation of cephamycin C biosynthesis in Streptomyces lactamdurans is exerted on the formation of $\alpha$-aminoadipyl-cysteinyl-valine and deacetoxycephalosporin $\mathrm{C}$ synthase. Journal of General Microbiology 132, 1805-1814. 
Felix, H. R., Peter, H. H. \& Treichler, H. J. (1981). Microbiological ring expansion of penicillin $\mathbf{N}$. Journal of Antibiotics 34, 567-575.

Hook, D. J., Chang, L. T., Elander, R. P. \& Morin, R. B. (1979). Stimulation of the conversion of penicillin $\mathrm{N}$ to cephalosporin $\mathrm{C}$ by ascorbic acid, $\alpha$ ketoglutarate and ferrous ions in cell-free extracts of strains of Cephalosporium acremonium. Biochemical and Biophysical Research Communications 87, 258265.

Jensen, S. E., Westlake, D. W. S., Bowers, R. J. \& WoLfE, S. (1982). Cephalosporin formation by cell free extracts from Streptomyces clavuligerus. Journal of Antibiotics 34, 1351-1360.

Jensen, S. E., Westlake, D. W. S. \& Wolfe, S. (1983). Analysis of ring expansion activity from Strepto: myces clavuligerus by ion-pair high-pressure liquid chromatography. Antimicrobial Agents and Chemotherapy 24, 307-312.

Jensen, S. E., Westlake, D. W. S. \& Wolfe, S. (1985). Deacetoxycephalosporin $C$ synthase and deacetoxycephalosporin C hydroxylase are two separate enzymes in Streptomyces clavuligerus. Journal of Antibiotics 38, 263-265.

Kohsaka, M. \& Demain, A. L. (1976). Conversion of penicillin $\mathrm{N}$ to deacetoxycephalosporin(s) by cellfree extracts of Cephalosporium acremonium. Biochemical and Biophysical Research Communications 70, 465-473.

Kupka, J., Shen, Y. Q., Wolfe, S. \& Demain, A. L. (1983a). Partial purification and properties of the $\alpha$ ketoglutarate-linked ring expansion enzyme of $\beta$ lactam biosynthesis of Cephalosporium acremonium. FEMS Microbiology Letters 16, 1-6.

Kupka, J., Shen, Y. Q. \& Demain, A. L. (1983b). Studies on the ring-cyclization and ring-expansion enzymes of $\beta$-lactam biosynthesis in Cephalosporium acremonium. Canadian Journal of Microbiology 29, 488-495.

LAEMMLI, U. K. (1970). Cleavage of structural proteins during the assembly of the head of bacteriophage T4. Nature, London 227, 680-685.

MarTin, J. F. (1981). Biosynthesis of metabolic products with antimicrobial activities: $\beta$-lactam antibiotics. In Actinomycetes, pp. 417-434. Edited by K. P. Schaal \& G. Pulverer. Stuttgart: Gustav Fisher Verlag.

Myllilla, R., Savolainek, E. R. K. \& Kivirikko, K. I. (1978). The role of ascorbate in the polyhydroxylase reaction. Biochemical and Biophysical Research Communications 83, 441-448.

SCHEIDEGGER, A., KuENZI, M. T. \& NuesCh, J. (1984). Partial purification and catalitic properties of a bifunctional enzyme in the biosynthetic pathway of $\beta$-lactams in Cephalosporium acremonium. Journal of Antibiotics 37, 522-531.

Shen, Y. Q., Wolfe, S. \& Demain, A. L. (1984). Deacetoxycephalosporin $\mathrm{C}$ synthase: importance of order of cofactors/reactant addition. Enzyme and Microbial Technology 6, 402-404.

Stapley, E. O., Jackson, M., Hernández, S., Mochales, S., Mata, J. M., Woodruff, H. B. \& Hendlin, D. (1972). Cephamycins, a new family of $\beta$-lactam antibiotics. I. Production by actinomycetes, including Streptomyces lactamdurans sp. Antimicrobial Agents and Chemotherapy 2, 122-131. Yoshida, M., Konomi, T., Kohsaka, M., Baldwin, J. E., Hershen, S., Singh, P., Hunt, N. A. \& Demain, A. L. (1978). Cell-free ring expansion of penicillin $\mathrm{N}$ to deacetoxycephalosporin $\mathrm{C}$ by Cephalosporium acremonium CW-19 and its mutants. Proceedings of the National Academy of Sciences of the United States of America 75, 6253-6257. 